\title{
DRIVERS OF LAND ABANDONMENT IN THE IRISH UPLANDS: A CASE STUDY
}

\author{
Eileen O'Rourke ${ }^{1}$
}

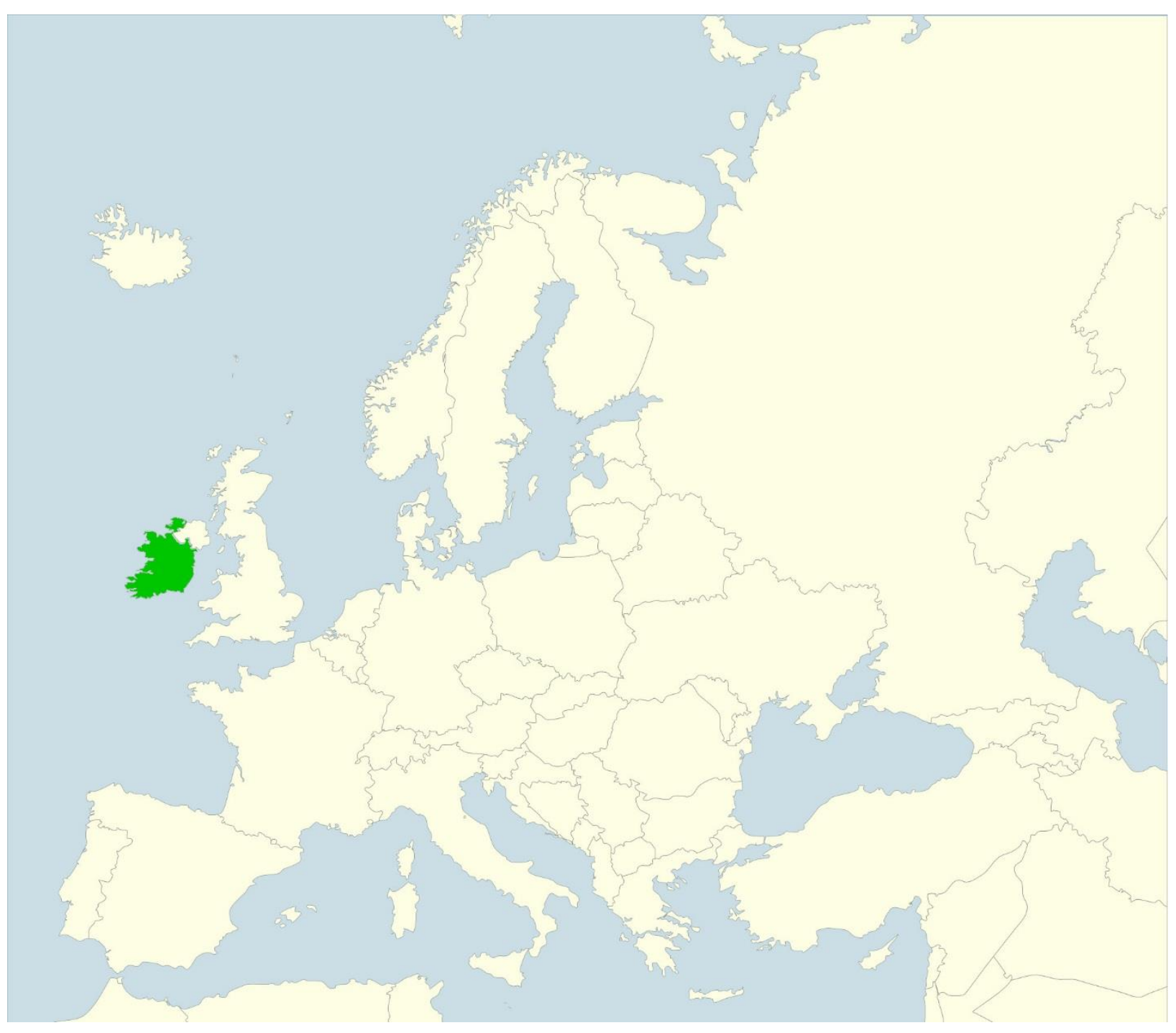

${ }^{1}$ Dr. Eileen O’Rourke, Department of Geography, University College Cork, Cork, Ireland, E-mail: e.orourke@ucc.ie 
Abstract: Land abandonment is a complex multi-dimensional process with interlinked economic, environmental and social aspects. This paper presents a case study of an isolated hill sheep farming community in SW Ireland, where a combination of low incomes, ageing population, lack of successors and strong environmental constraints are perceived to be among the main factors leading to their demise. However, the uplands they have grazed for generations are of high nature conservation value, and depend on active management to maintain both their ecology and landscapes. The research, which is based on a combination of interviews and farming systems research, highlights the misfit between what the mountain can produce, light hill lamb, and what the globalised market demands. The paper argues that if 'farming for conservation' is the new function of such farming systems, then we should consider decoupling public goods payments from agricultural subsidies, along with integrating agriculture in disadvantaged areas within a broader rural development framework. The research aims to fill the gap between macro policy and the micro reality of an upland community on a self-declared 'tipping point'.

Key words: land abandonment, uplands, high nature value farming, ecosystem services, cultural identity

\section{Introduction}

There is currently considerable debate around land abandonment in Europe, its drivers and the social and natural consequences. The general consensus is that farmland abandonment is occurring primarily in areas where agriculture is less productive, particularly in remote and mountainous regions and areas with poor soil and a harsh climate, and in Eastern Europe as a result of political change since the 1990s (Keenleyside and Tucker, 2010; Baldock et al., 1996; MacDonald et al., 2000; Kristensen et al., 2004; Strijker, 2005; Prishchepov et al., 2013). It results largely from the decline in the viability of extensively managed, low input, small scale agricultural systems that are often of high nature conservation value. Around half of Europe's network of Nature 2000 sites are farmed environments (Halada et al., 2011), and over $30 \%$ of EU farmland is estimated to be High Nature Value (HNV) (EEA, 2010, 2004; Parachinni et al., 2008). Projected estimates of European Union (EU) farmland abandonment by the year 2030, vary greatly from possible highs of $8 \%$ (Renwick et al., 2013), under an increasing trade liberalisation and low Common Agricultural Policy (CAP) subsidy scenario, to more conservative mid-range estimates of 3-4\% (Keenleyside and Tucker, 2010) (see also Verburg et al., 2010; Verburg and Overmars, 2009; Pointereau et al., 2008).

Keenleyside and Tucker (2010) argue that land abandonment is difficult to define, measure and study, and varies from semi-abandonment to various forms of permanent or transitional abandonment. The impacts of abandonment vary according to context, nevertheless, it is clear that large areas of semi-natural habitats, often dependent on extensive grazing systems, will be affected in the coming years and there will be socio-cultural, biodiversity, landscape and other environmental services and public goods consequences (Paracchini et al., 2008; Bignal and McCracken, 2000; 1996). Land abandonment is a complex multi-dimensional process with interlinked economic, environmental and social aspects (Renwick et al. 2013; Verburg and Overmars 2009).

It is also argued that some land abandonment and rewilding (i.e., the passive management of ecological succession) may prove beneficial for habitat restoration and reforestation, particularly in highly fragmented landscapes (Navarro and Pereira, 2012; Pointereau et al., 2008; Höchtl et al., 2005). In biodiversity terms, there would be losers and winners, but it is clear that much of the agri-biodiversity associated with extensively managed high nature value (HNV) farmland would be in the loosing category (Plieninger and Bieling, 2013; Plieninger et al. 2006). Terres et al., (2015: 21) define land abandonment as a 'cessation of land management which leads to undesirable changes in biodiversity and ecosystem services'. Land abandonment would also 
bring about major changes to European cultural landscapes and the societal values associated with them (Daugstad et al., 2006; Antrop, 2005; Hanley et al., 2007). As Adams (2003) and Rackham (2000) remind us, the countryside has a history and so do the habitats within it. Farmed landscapes evolved as tightly coupled social-ecological systems and traditionally people received direct benefits from their environment. The crux of the problem today as expressed by Fischer et al., (2102), is that globalised markets and rural development programmes have altered the social subsystem in traditional farming landscapes, whereas conservationists seek to preserve the ecological subsystem. The traditional links between people and nature are broken, however the humanised landscapes of Europe require active management. The reduction of labour intensive traditional practices is as argued by MacDonald et al., (2000), as valid a threat to biodiversity as physical land abandonment. The European Union via its 1996 Cork Declaration (www.ec.europe.eu) aspires to a lived-in countryside and the EU Common Agricultural Policy (CAP) supports farming in disadvantaged and marginal areas via its Second Pillar, the Rural Development Programme. Even if farming in such areas can no longer be justified in terms of the production of food and fibre, its new function is seen to lie in the provision of environmental goods and services demanded by society, including countryside management (Bonn et al., 2009; Burton et al., 2009; Hanley et al., 2007).

Drivers of land abandonment are complex, multidimensional and include such interlinked processes as agricultural intensification and marginalisation, farm structure, biophysical conditions, remoteness, accessibility, socio-economic factors, ageing population and demographic decline, globalisation of markets, lack of economic viability and agricultural support payments, among others (Renwick et al., 2013; Keenleyside and Tucker 2010; Terres et al., 2015; MacDonald et al., 2000; Conti and Fagarazzi, 2004; Prishchepov et al., 2013; Rey Benayas et al., 2007; Pinto-Correia and Sørensen, 1995). Low intensive livestock systems on poor mountainous land, the subject of the below case study, ticks all the boxes. Keenleyside and Tucker $(2010: 11)$ remind us that model projections of farmland abandonment need to be interpreted with great caution, as they vary according to socio-economic and policy assumptions, and because ultimately abandonment is context specific. Or rather farmers' responses to the various driving factors is context specific, and similar combinations of drivers can produce quite different responses at local levels. Factors driving change cannot be separated from factors driving location (Verburg et al., 2002).

This paper aims to expose the drivers of land abandonment in a context specific case study set in the uplands of SW Ireland. Local case studies are important for understanding fine scale patterns that drive land cover change and are still among the best approaches to understanding complex human - nature systems (Lambin 2003; Mottet at al. 2006). In the below research, micro empirical knowledge of farming systems and socio-economics is entwined with insight into the local culture and mentality, which is critical in understanding the inhabitants' decision-making process and ultimately their likely future options. Of course the place is not unique, rather it is an indicator whose underlying dynamics have wider applicability in the Irish and European uplands in general. The study aims to fill the gap between macro policy and the micro reality of an upland community on a self-declared 'tipping point'.

\section{Methods}

This research concentrates on a typical mountain valley with a clear geographical unity, on the Iveragh peninsula, County Kerry, SW Ireland. The Iveragh uplands have been the subject of previous ecological and farming systems research, thus the wider context is well known (O'Rourke and Kramm 2012; O'Rourke and Kramm 2009; Kramm et al. 2010; Anderson 2013). The current study concentrates on the Coomasaharn-Canearagh valley, comprising the townlands of Coomasaharn, Canearagh and Tooreenealagh and covering an area of approximately $15 \mathrm{~km}^{2}$ (see Fig.1). The research is based on seven months field work in the valley in 2014, and adopted a broadly ethnographic approach whereby participant observation was combined with 23 semi-structured interviews (see Table 1). Twelve of the interviewees were inhabitants of the valley, all involved in agriculture. Four of the interviewees were farmers from 'outside' who either bought or inherited land in the valley, and the remaining seven were people with official links to the area such as agricultural advisors, local politicians, tourism and rural 
development experts. All the interviews lasted a few hours, and several interviews / conversations with the valley hill farmers' involved up to three repeat visits, including walking the mountain or herding sheep in their company. The in-situ interviews with the inhabitants of the valley concentrated on the hill farming system and its socio-economics, farm management practices, land-use change, farm diversification, the social context and their vision for the future. Attention was also paid to their underlying mentality, their decision-making process and what they perceived as the main issues impacting on their farming system and ultimately, way of life. The interviews with outside officials provided supporting information on the broader context. This was supplemented by agriculture and demographic statistics and data on farm ownership in the valley, obtained from the Government Land Registry (www.prai.ie). All the interviews were qualitatively analysed. The overall objective was to produce an ethnographic rich narrative based on a micro-scale case study, but which informs our understanding of macro-scale processes occurring in similar contexts throughout Europe.

Tab 1. List of Interviewees.

\begin{tabular}{|l|r|}
\hline Active Farmers in the Valley & 6 \\
\hline Retired Farmers in the Valley & 1 \\
\hline External Farmers with Land in the Valley & 4 \\
\hline Valley Farmer's Wives & 3 \\
\hline Mothers of Valley Farmers & 2 \\
\hline Rural Development Experts (Local) & 2 \\
\hline Tourism Expert (Local) & 2 \\
\hline Local Counsellor /Politician & 1 \\
\hline Farm Advisor (Teagasc) & 1 \\
\hline Environmental Expert & 1 \\
\hline Total Interviewees & $\mathbf{2 3}$ \\
\hline
\end{tabular}

\section{Introduction to Field Site}

The Coomasaharn-Canearagh valley essentially consists of cut over blanket bog from which much peat or turf was extracted in the past, and is in parts still used for peat extraction today (see Fig. 2). The farm houses are surrounded by privately owned fields of stony rough grazing, some of which have been reclaimed (known as 'green land'), but still remain quite unproductive. The landscape and farming system is dominated by the upland commonages of Coomasaharn, Canearagh and Tooreenealagh, typically reaching elevations of 700 to 800 metres. The commons, or 'common lands', are managed on a share-holding (rather than grazing rights) basis, which means that the commoners own the commons. A few of the farmers in the valley have bought or are renting land elsewhere on the Iveragh peninsula, generally in an effort to produce some winter fodder of hay or silage. Overall, the land holding system is very fragmented, each with its inherited lottery of good and bad land. The Coomasaharn glaciated cirque lake, where Arctic Char are to be found, dominates the southern end of the valley (see Fig. 3). A small coniferous forest plantation is to be found on the southern side of the lake in the townland of Tooreenealagh, which is now deserted, with the remains of five simple two roomed roofless cottages dotted around the landscape near the lake. Annual rainfall on the Iveragh peninsula is high ranging from $1,350 \mathrm{~mm}$ to $3,000 \mathrm{~mm}$ in elevated places like Coomasaharn-Canearagh (www.met.ie). Even in the summer time, one can hear the gushing of mountain streams as they race to the coast about $12 \mathrm{~km}$ away. The hamlet of Coomasaharn along with the few dispersed farmsteads of Canaeragh are situated about $8 \mathrm{~km}$ from the main road, and the road leading into the valley is very narrow and in poor condition. 


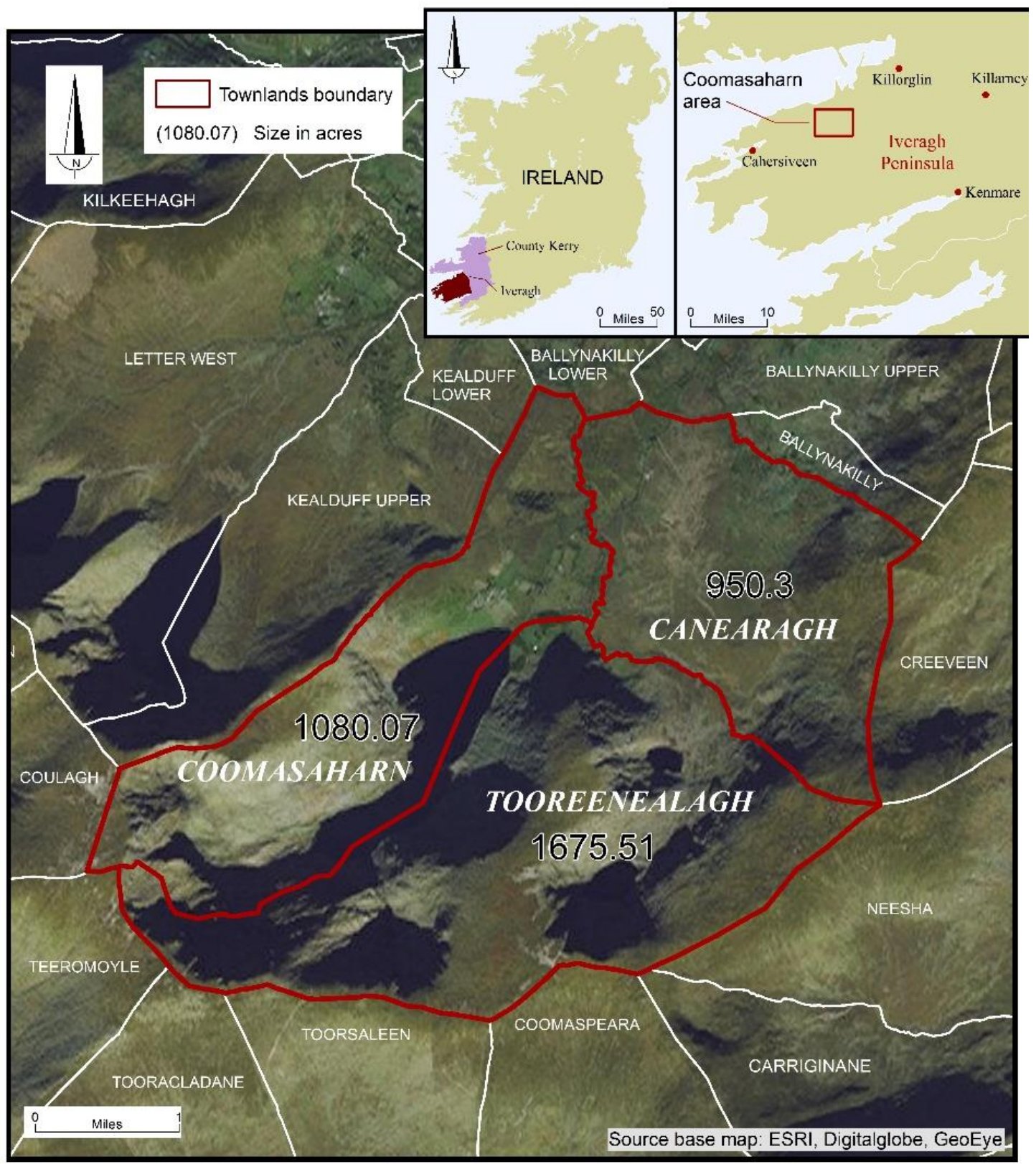

Fig 1. Field site location map showing the townlands of Coomasaharn, Canearagh and Tooreenealagh. Source: map produced by Mike Murphy, Cartographer in the Geography Department, University College Cork).

There are six active farmers living in the valley today, ranging in age from 50 to 79 years, and four of whom are unmarried. Only one of the farms has a designated successor, who currently works fulltime off-farm. The concentration of bachelor farmers, often caring for elderly parents, is striking. This trend commenced some time ago when it is said that many women refused to marry into the perceived drudgery and poverty of hill farms, preferring instead to emigrate. This along with depopulation marked the start of the fraying of social resilience in the valley. The total permanent population of Canearagh today is three, thirteen in Coomasaharn, and Tooreenealagh is deserted (Census of Population, 2016). The elderly people remember a time in the $1950 \mathrm{~s} / 1960 \mathrm{~s}$ when there were fifty people living in Canearagh and sixty in Coomasaharn, and the valley was full of the sounds of children going to school over a mountain path to Letter National School. One should note that the large population of the past lived a semi-subsistence life. They grew all their own vegetables (the potato being the staple food), had mutton from the hills and cut their own turf which was their sole source of fuel. Emigration, generally to England or America, was the only option for the young people without land. 


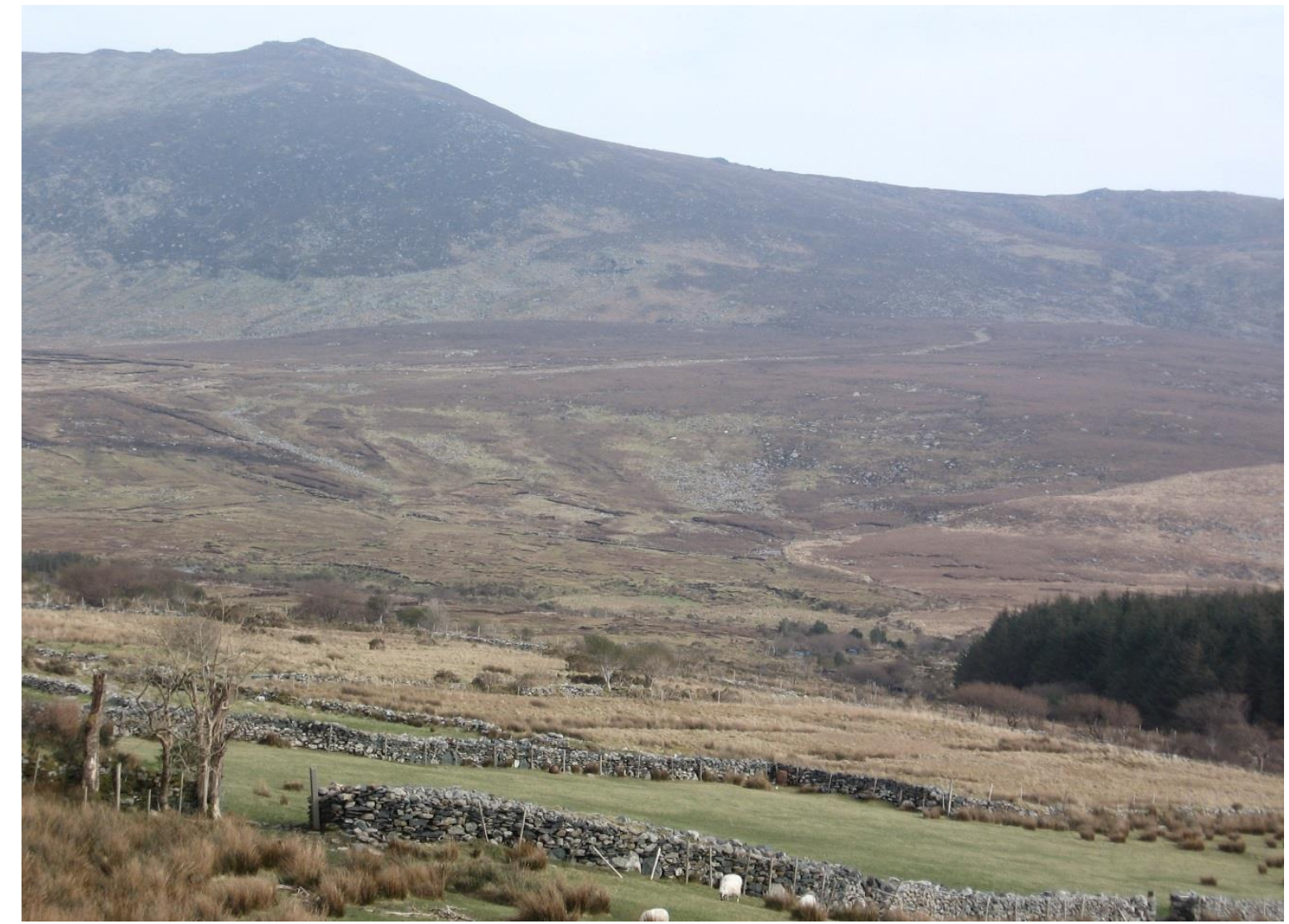

Fig 2. Coomasharn-Canearagh mountain valley with scree covered mountain and cut-over bog in the background, and rough grazing in the foreground. Source: Author

Apart from the above-mentioned resident active farmers, there are four farmers from outside the valley who have bought and/or inherited land in the valley, mostly for access to commonage, and are locally referred to as 'people coming-in', and none of whom live in the valley. At the entrance to the valley, some cutover bog (with no commonage rights), was bought by outside investors some years ago, essentially for its entitlements/subsidies. This land is fenced off and abandoned. It is today covered in regenerating scrub, 'rewilding', and is seen as a potential fire risk. The area around Coomasaharn lake is particularly scenic (see Fig. 3). All the uplands in the study area are designated as Special Areas of Conservation (SAC), as defined under the European Habitats Directive (Directive 92/43, May 1992), in recognition of their internationally important blanket bog and moorland habitats. There are legally binding restrictions on development and land use within SAC areas.

Many families in the valley are inter-related or inter-married, which is reflected in the dominance of a few surnames. The land and its ownership is still sacred, and a woman who recently put her small farm in the valley up for sale, stated that if she sold to an outsider, she dared not show her face in the valley again. Part of the desire to keep 'unknowns /strangers' out is the fear of having a difficult neighbour and the problems that could cause in relation to managing the commons, which dominates the land tenure system in the valley. However, one can observe the emergence of a trend whereby a few 'strong' farmers from outside the valley are buying-up or inheriting farms in the valley when they become available and manage them from a distance. For example, one of these 'outside farmers' has over 1,000 sheep on various holdings throughout the Iveragh peninsula, including in the valley. This trend is repeated throughout the Iveragh uplands. It marks a move towards larger holdings, less labour input and a simplification of the management system, with the first areas to be abandoned being the steeper slopes and those that are difficult to access (O'Rourke and Kramm, 2009; Cocca et al., 2012; Mottet et al., 2006). It also leads to more depopulation of the valley. 


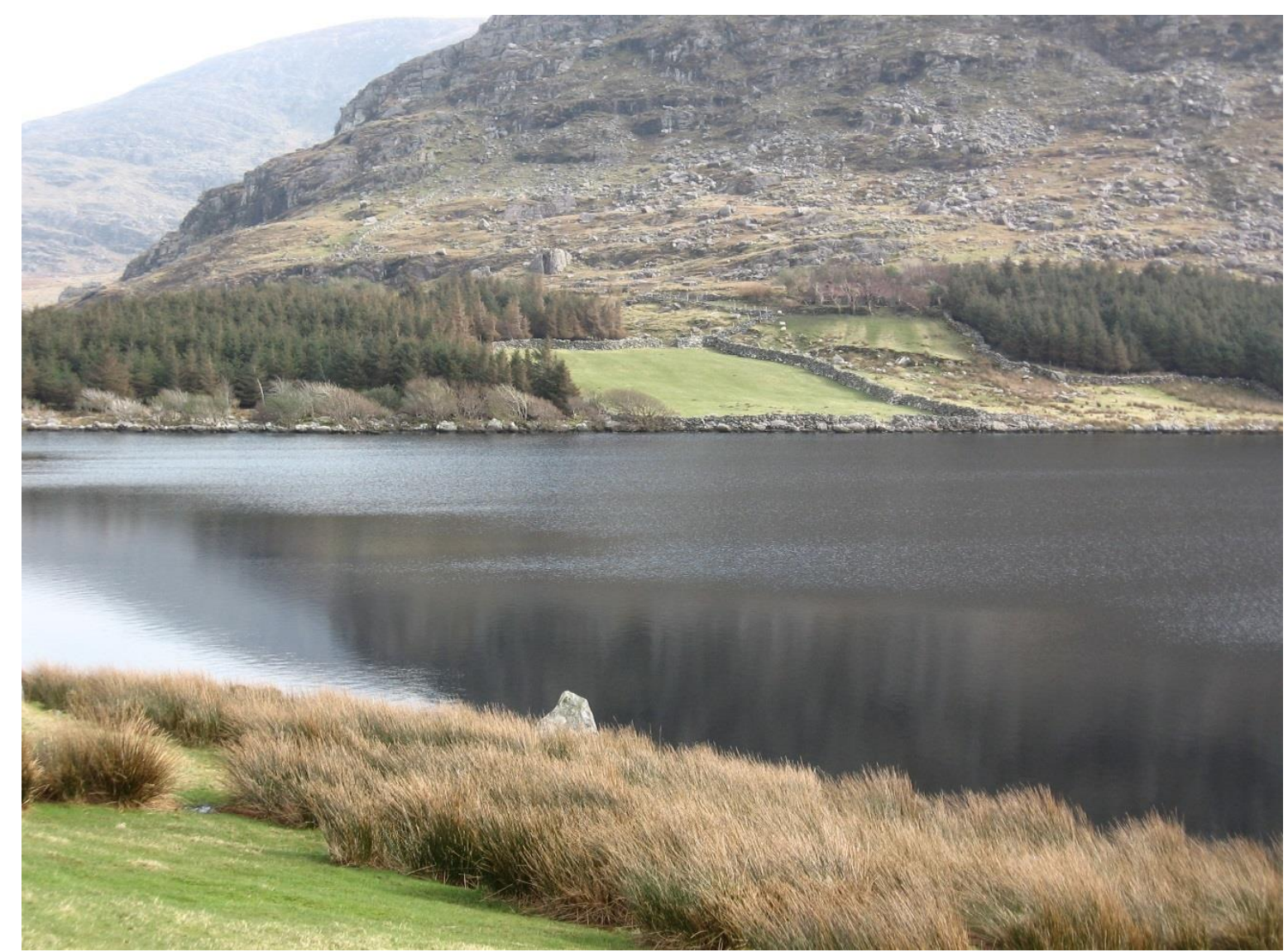

Fig 3. Coomasaharn cirque lake, showing conifer forest plantation and reclaimed green land in the background. Source: Author

Currently, land abandonment is not a major issue in the valley, in fact parts of the mountain are still overgrazed. But, not only can abandoned land be observed at the entrance to the valley and throughout the Iveragh peninsula, there is a general consensus in the study area that it is what the local people refer to as a 'tipping point', and that the current generation of hill farmers will be the last to farm the mountain in the way they have traditionally done for generations, albeit with adaptations. One is frequently reminded that 'soon there will be no one here' and that the mountain 'will go wild', meaning out of human control, something that is always perceived in negative terms. What is happening in the Coomasaharn-Canearagh valley is typical of many other isolated places throughout the Iveragh and Irish uplands in general.

\section{Farming System}

On paper, the valley's farm sizes of 100-430 hectares look big when the vast commonage shares are added to the privately-owned lowland, but practically all of it consists of peatland, stony rough grazing or scree covered mountain. The majority of farms in the Coomasaharn-Canearagh valley do not produce any fodder, with the buying-in of feedstuff hay/silage and especially meal concentrates for the sheep, being the largest source of farm expenditure. The dominant farming system in the valley and throughout the Iveragh peninsula is hill sheep farming. The traditional sheep breed is the hardy mountain Scotch Blackface that live outdoors on the mountain all year round, being brought down to lower ground in March prior to lambing in April/May. The ewes are supplementary fed with bought-in cereal based feedstuffs around lambing time (March - June) prior to being put back up the mountain. The feeding of the ewes and female replacements, known as 'hoggets', along with the removal of rustic cattle from the uplands, is perceived as one of the biggest changes to the 'traditional' hill farming system practiced by their forefathers. The reason given for supplementary feeding is firstly, flock sizes are much larger now than in the past (their parents time), when average flocks were about 60-80 ewes, as opposed to averages of 300-400 sheep today; thus, there is greater grazing pressure on the commons. 
The large flocks of today are seen as a consequence of the European headage production subsidies of the 1980s and early 1990s, and also in the past they did not have the winter fodder (or capacity to purchase it) to keep large flocks. This trend is born out in the census of agricultural for the Cahersiveen Rural District, a statistical division which covers most of the Iveragh peninsula, and is the smallest area (80,169 ha) for which long term agricultural statistics is available. Between the 1980 and 1991 census, the total number of sheep in the Cahersiveen Rural District rose by 51\%, or a 72\% increase between 1933 and the peak of 1991 (Census of Agriculture, 1933 to 2011). Between the 1991 and 2000 census, there was an $18 \%$ reduction in sheep numbers, probably reflecting the compulsory destocking of overgrazed commonages under the 1998 Irish Commonage Framework Plan. The landmark 2005 European Single Farm Payment (SFP), which de-coupled subsidies from production ${ }^{2}$, and effectively made the transition to supporting farmers' incomes rather than farm production, has as yet not had a large effect on stocking levels, with only a $2.6 \%$ reduction in sheep numbers between 2000 and the most recent 2010 census. As stated by one of my interviewees, with low lamb prices and high prices for feedstuff, the trend is towards reducing sheep numbers, but it takes a while to get out of something'. It was also frequently pointed out, that it was those who overstocked most in the past that were subsequently rewarded with the highest Single Farm Payment (as it is based on historic income data). This is another reason they do not blindly follow policy and subsidy incentives: the hill farmers fear that if they reduce sheep numbers now, they may not be able to get back into them if a new quota system or policy is introduced in the future.

The principal reason for the supplementary feeding of sheep today is that there is no market for light store lambs off the mountain, with export markets demanding lambs of over $40 \mathrm{~kg}$. The sheep farmers must provide supplementary feeding to their hill lambs just to bring them up to 28 to $30 \mathrm{~kg}$, before they are bought by buyers at the farm and sent to factories up the country for fattening and slaughter. A number of farmers attempted to fatten lambs but gave it up because it was uneconomical, the higher lamb prices were eaten up by cost of bought-in feeding, not to mention the extra labour, which they never cost. All the farmers were unanimous in stating that their biggest problem is the poor price of their principal product, hill lamb, which in 2014/2015 was making just $€ 38$ (for $28 / 30 \mathrm{~kg}$ lamb), and about $€ 70$ for a $40 \mathrm{~kg}$ lamb. Prices also fluctuate from year to year, with hill lambs making about $€ 55$ in 2010/2011, and about $€ 60$ in 2016 . Some farmers have started crossing their rustic Blackface sheep with heavier lowland breeds such as Texel, in order to produce a heavier lamb, but the cross breeds are not suited to rough mountain grazing and are never kept as breeding replacements. Some interviewed hill farmers predicted that in time the hill breeds will completely die out and sheep farming will become a lowland affair. In the past, the lambs were sold off the hill as two to three year old 'wethers' (as opposed to after 4 to 5 months today), but there is no market for this lamb today, as consumers consider the flavour too strong and the meat too fatty. The farmers themselves believe it is the most flavoursome and best quality lamb, which some still produce for their own household consumption. The lack of a market for light weight hill lamb lies at the crux of the economic viability of both the farming system and way of life in upland environments like Coomasaharn-Canearagh. As remarked by Burton and Schwarz (2013: 638) 'without economic capital, cultural and social capital are unsustainable'.

Most of the Coomosaharn-Canearagh hill farmers also have a small herd (6-14 cows) of Limousine suckler cows that spend most of the year indoors in slatted cattle sheds. One farmer carries Limousine Shorthorn crosses that are not housed. In the past, many of these farms would have kept small herds of rustic Kerry or Dexter cows, that lived outdoors all year round and grazed the uplands (after the sheep has passed) from April to November. It is believed both locally and by experts that a combination of cattle and sheep are the most effective grazers for managing the uplands (Backshall et al., 2001). However, the continental Limousine breeds are unsuited to the rigours of the mountain, but their calves fetch almost double the price at the market to the former light weight rustic breeds, for which there is no market nowadays. Limousine cattle held in-doors for most of the year, and for which all feedstuff has to be bought-in is an anomaly in a mountain farming system and is probably loss making. The local farm advisor referred to it

2 The decoupled SFP breaks the link between the number of livestock and farm household income. It is based on historic payments prior to decoupling. 
as a 'fashion', and a hang-over from the traditional mixed sheep and cattle mountain grazing regime of the past. There is also the added problem of disposing of the slurry in this sensitive SAC environment.

\section{Farm Income}

The net farm income in the valley ranges from $€ 10,000$ to $€ 18,000$ a year, in line with the 2014 average National Farm Income from the sheep sector of $€ 11,731$ (Hanrahan et al., 2014), rising to $€ 16,011$ in 2016 (Dillon et al., 2016). The most important income source is from European subsidies, in particular the Single Farm Payment (SFP), Area Aide (a Natural Handicap payment), and Agri-environment subsidies. In terms of animal sales, they are running at a loss (see also Acs et al., 2010). The new 'function' of agriculture in naturally handicapped places like the uplands is, as previously stated, seen to lie in the provision of environmental goods and services, including the maintenance of scenic cultural landscapes, water sources, biodiversity and related habitats. However, as currently structured 'public goods' does not support farm incomes, while conservation area designations can actually suppress them (Crowley et al., 2016). This leaves marginal upland farmers heavily reliant on farming subsidies and off-farm incomes.

The Coomasaharn-Canearagh hill farmers are essentially using their income from EU subsidies to subsidise their loss making sheep and cattle enterprises, with bought-in feedstuffs being their biggest farm expenditure. They were asked why they continue to carry large stock numbers, when under the current decoupled SFP, it would be economically more profitable for them to live from subsidies and the required minimum stocking density of 1 ewe per ha for cross-compliance purposes. They unanimously replied that they could not do that, they are farmers after all and they have to 'produce a product'. Their active engagement with the landscape relates to production, and reclaimed 'green land' is always admired. They also stated that they had to have a reason for 'getting out of bed in the morning' (see Burton and Schwarz, 2013; Fischer et al., 2012). They believe that without the sheep they would be lost and would not know what to do all day. Without verbally expressing it, sheep farming is obviously an important part of their cultural and social identity. They accept that they are what is locally referred to as 'Busy Fools'. Renwick et al., (2013) also observed that landowners will continue uneconomic farming (and supplement income in other ways) for a variety of social and cultural reasons. The reality is that many of the Coomasaharn-Canearagh hill farmers, especially the bachelors, do not know or care if their enterprise is loss making or not. They are traditionalists who do what they have always done and believe things will work out eventually (O'Rourke, 2012). Contrary to policy assumptions, they are not rational economic actors (Burton and Paragahawewa, 2011). Practically, all of them inherited their farms and apart from one 'progressive' farmer, they are not carrying large financial debt. The critically important thing for them is 'to carry on', to be able to say 'we are still at it', like a badge of defiance or resistance. The fear was also expressed that if one does not keep up their stock numbers on the commons, another neighbour (shareholder) would take advantage and increase their stock numbers. Flock size is also linked with social status, something I shall return to later. In fact the most over grazed commonage in the valley (Canearagh), carrying a heavy stocking density, is managed by three bachelor farmers in their sixties, with no successors.

\section{Mentality}

Why would bachelor farmers with no successors continue to overstock a mountain, even when it is uneconomical to do so? From the interviews, it became clear that the hill sheep farmer's social identity and perceived standing in the community is still linked with being an active farmer with a large flock size. Certain family names were always associated with being big farmers, and it is perceived to be important to be carrying on that family tradition, as well as maintaining the family name on the land. The interviews indicate that the overwhelming motivation for the majority of farmers in the valley is 'tradition'. They want to fulfil the inherited responsibilities entrusted on them by their parents and their parents before them, regardless of the shifting policy/subsidy environment that ultimately dictates the viability of their farms. Many also stated that if possible, they would like to expand or improve their farm, reclaim more 'green land', and of course make a living. During conversation, they often referred to their parents/ancestors as the 'old people'. They see themselves as the upholders of the traditional knowledge of the 'old people', which they 
believe is central to farming the uplands that they are strongly attached to. In Norwegian mountain farms, studies have also found a sense of duty towards previous and future generations, along with the notion of being stewards, not owners, of the land (Shucksmith and Ronningen 2011; Daugstad et al., 2006; Flemsæter and Setten, 2006). It has always been difficult to make a living in places like Coomasagharn-Canearagh where the environmental constraints are strong. Not surprisingly, they are risk averse and the passed down wisdom of the tried and trusted ways of the ancestors is respected. Resistance to change is what defines them, and helps explain their 'resistance identity' (see also Rebanks, 2016). Paniagua (2013: 1) argued that 'resistance suggests permanence' and can be associated with the concept of rural resilience. Their resistance to change is also a source of vulnerability. They march to a different value system, a different world vision, out of step with today's multifunctional, postmodern, globalised world. Their biggest fear is that there will be no one here in the future and all that mountain and sheep knowledge will be lost, the mountain will 'go wild'.

None of the hill farmers interviewed felt either geographically or socially isolated, even though they could go for days without meeting anyone. Many expressed the delight of returning home to the peace and tranquillity of their mountain and sheep after a noisy day in town. Their attachment to the place and the land is based on what Selman (2004) referred to as a deep experiential engagement, purposefulness and heritage as opposed to new relationships with the land of aesthetics, scenery and recreation. Their active engagement with the landscape relates to production, not conservation and terms like 'ecosystem services' are meaningless to them ${ }^{3}$. They manifest a strong sense of place, but the sense of community is more debatable. The community today is depopulated and fragile, and the petty jealousy and begrudgery of the past still lie just under the surface. Similarly, the collective management of the commons in terms of regulating stocking density, burning the heather, fencing and the 'gathering' of sheep at certain times of the year for dipping, shearing or lambing, has broken down (Ostrom, 1990). A number of commoners expressed the belief that the commons should be divided into private shares, but it was felt that it would be impossible to get agreement on equitable divisions. Overall, one has to rely on oneself, a good sheep dog and extended family (often a brother) when necessary. One informant stated that the local mentality is 'stubborn and closed'. Ironically, it may well be their obstinate spirit of 'resistance' and lack of innovation that binds these people to this place. The vast majority of farmers interviewed stated that they had lived a good life, they loved hill farming and being one's own boss, adding that they would do it all over again. They feel abandoned by local politicians (too few votes), and alienated from the power brokers in Dublin and Brussels, whom they believe want to 'close down the countryside'.

\section{Social Reality}

Isolation is a perception, and as previously stated none of the people interviewed who came from the valley (including all the bachelor farmers) felt either socially or geographically isolated. The few people who have married into the valley, especially two mothers with young families, see things differently. They feel strongly the difficulty of bringing up a family in such a geographically isolated place with poor services, to the extent that one woman with a young family is adamant that they are moving out. She had to give up a good job in a nearby town, due to the lack of childminding facilities. When the children start school, they have to be driven in and out of the valley a few times a day to catch the school bus. In short, the mothers' of young children spend their day on the road, which is both expensive and time consuming and not compatible with working outside the home. They also expressed the belief that the lack of services in the valley, in particular, internet access, puts their children at a further disadvantage, with one mother opting to drive her children back into town in the evening so that they could access internet, which is often necessary for school homework, in a friend's house. There were plans to build a telecommunication mast in the valley a few years ago, but it never materialised as there were too many objections to it, both from people in the valley and in the surrounding area, mostly on health grounds. The lack of broadband also hinders the option of working from home. The lack

\footnotetext{
3 In policy terms we have, as argued by Mansfield (2008: 180), 'moved from a situation where environmental goods are the by-product of farming to a situation where farming is a by-product of environmental goods'.
} 
of social capital, community cohesion and basic services adversely affects the adaptive capacity of what was once a tightly couples social-ecological system.

\section{Farm-Diversification / Multifunctionalism}

The Coomasaharn-Canearagh valley with its lake and surrounding mountains is spectacularly beautiful and scenic. At first glance, one would think that it is well placed to capitalise on the European multifunctional or farm diversification policy, which is one of the major objectives of the EU Rural Development Framework (Renting et al., 2008; Wilson, 2001; Mansfield, 2011). The concept of multifunctionality was developed in the late 1990s to encapsulate the reorientation of the agricultural sector in less productive areas towards the provision of environmental and other public goods, and ultimately fosters 'post-productivism' (Shucksmith and Ronningen, 2011). Marginal hill farmers in places like Coomasaharn-Canearagh are encouraged to diversify into such activities as agri-tourism or to add value to their produce by developing niche marketing and 'terroir' labelling. Theoretically, it provides a possibility for reconnecting people and nature (Fischer et al., 2012). But nobody in the valley profits from tourism, even though it is just off the famous 'Ring of Kerry' scenic coastal route and part of the 'Wild Atlantic Way' that circles the Iveragh peninsula. The inhabitants of the valley claim that it is too isolated for tourists to want to stay there. In the past, an hotelier from a nearby village used to bring tourists on walking day trips to the valley, and still today the valley is used by individual and group organised hill walkers, but there is no economic return to the local inhabitants from these activities. In fact, there are only inconveniences with indiscriminate parking blocking roads and field entrances. There is also the fear of walkers leaving gates open, knocking fences and worst of all, bringing dogs onto the mountain. Most of the farmers are not hostile to tourist/walkers, but their major concern is the lack of clarity around public liability insurance - who is responsible if a walker falls and injures themselves (see www.mountaineering.ie)? None of the farmers in the valley have public liability insurance, as it is deemed an expense they can ill afford. Others spoke of the difficulty of getting planning permission for potential tourism or farm diversification projects within an SAC designation. For multifunctionalism to work, especially in marginal depopulated areas like the Coomasaharn-Cannearagh valley, it would require a lot more input and support from national and regional government that could, for example, work towards improving hill lamb quality, launching a quality 'terroir' label, diversifying into agri or eco-tourism. These are not things that some elderly hill farmers without internet access and who left school at fourteen years of age, are likely to ever achieve on their own.

All the interviewed hill farmers declared that they had neither the interest, mentality, skills, nor capital to invest in agri-tourism or farm product transformation. But some of their successors, including the few younger women who married into the valley may be more entrepreneurial. The preferred survival option has traditionally been to combine farming with off-farm work. In the past this involved seasonal agricultural work on lowland farms or in the UK and Scotland. It has been argued that farm diversification and off-farm work encourages further marginalisation and simplification of farming practices (Lopez-i-Gelats et al., 2011). Alternatively, it has also been shown to be an important farm survival strategy, and does not necessarily represent 'people on their way out of farming' (Kinsella et al., 2000). Pluriactivity is increasingly a structural phenomenon, especially in marginal areas where the ability to tap into a variety of income sources has enabled farmers to stay on the farm (O'Rourke et al., 2016; Crowley et al., 2016).

\section{Future Prospects}

Because of their physical constraints, geographical remoteness and climatic conditions, upland areas represent an extreme case of economic and social vulnerability. There was general agreement in the Coomasaharn-Caneargh valley that there will be big changes there in the next ten to twenty years when the existing farmers, practically all without successors, will have died out. In terms of the future, one possible scenario put forward is that it will be a combination of land abandonment and 'ranch farming', whereby large outside farmers will buy up farms and commonage rights and adopt a ranch style farming system, where large flocks of sheep are left to their own devices on the mountain. This is already happening on parts of the peninsula. With the reduced labour input and infrequent checking of sheep, there may well be animal husbandry 
problems, but as it is sheep/lambs are not valuable enough to warrant veterinary costs. Such farms would be managed from a distance and the valley would eventually be depopulated. The ranch farmers will do 'their sums', and will essentially be farming subsidies. This option would bring about large changes to the cultural landscape, vegetation and biodiversity of the uplands. A similar trend was remarked on by Paniagua (2013) in remote areas of rural Spain, where as a consequence of rural exodus the few remaining farmers took over all the farming land in the municipality. Another possible scenario is the rewilding of the mountain and regenerating forest, in line with the increased liberalisation of trade and reduction in CAP subsidies (Navarro and Pereira, 2012; Jørgensen, 2015; Vera, 2000). This would also have a negative biodiversity impact, as studies show that both under and over grazing adversely affect upland biodiversity. Biodiversity peaks for low levels of land use, associated with extensive grazing, following the ecological intermediate disturbance principle (Grime, 1979; Evans et al., 2006; Hanley et al., 2008). Rewilding would also mark the end of human habitation in the valley. A third scenario is based on the continuation of a family hill farming system, provided it could be combined with offfarm work, along with more direct payment for public goods provision. This option is predicated on the availability of off-farm work and thus the socio-economic development of the peninsula. Full-time farming cannot ensure viable upland communities. Currently, $25 \%$ of the active male population in the Cahersiveen Rural District are employed in agriculture (Census of Population, 2016). The over dependence on Primary Sector employment is a measure of the under development of the local economy. Ultimately, it will take political decisions at the national and European level, along with pro-active policies on the ground, to actively promote employment and HNV farming in isolated areas like the Iveragh peninsula, or the future will be wide scale abandonment. This in turn would have a major impact on the thriving tourism industry in the County which is dependent on 'consumption landscapes' for tourism and recreation (see Buijs et al., 2006).

Effective policies for the conservation of mountain farming systems and the associated environmental goods and services demanded by society must, as demonstrated by the above case study, take into account social and economic objectives as well as ecological and landscape issues in an integrated manner. As argued by Pinto-Correia et al. (2006: 340), "If the intention is to maintain living landscapes, many more aspects of the rural life have to be supported or recreated in new ways and combinations. Rural society is in decay and it no longer has a close and functional relation with the landscape". Alternatively, Marini et al., (2011) suggest that the decline of traditional agriculture appears to be largely inevitable because it is closely linked to a broader process of social transformation. This certainly rings true in Coomasaharn-Cannearagh with its out-migration and elderly bachelor farmers. If public goods and environmental services is ultimately the raison d'etre of farming in such marginal but high nature value areas then that needs to be translated into income on the ground, which is not currently happening. One way of doing this would be by shifting emphasis to locally-defined and evidence-based agri-environmental policies, possibly along with access payments for tourists and hill walkers (Keenleyside et al., 2014; Renwick et al., 2013; Burton and Schwarz, 2013). This would effectively mean decoupling public goods payments from agricultural subsidies. Several studies have also called for policies and national strategies specifically targeted towards upland and mountain communities (CRC, 2010; CEDRA, 2014).

\section{Conclusions}

The fragility of both the community and hill farming system in the Coomasagharn-Canearagh case study is driven by a lack of economic viability, along with an inability to supplement farm income by either off-farm work or farm-diversification. This along with an ageing population, lack of successors, geographic isolation and poor infrastructure, means that the once tightly coupled social-ecological system is unravelling. The strong environmental constraints to productionoriented agriculture, which means that the hill farmers' will never be able to compete on globalised markets. If the environmental goods and services of the existing HNV farming system are to be maintained by agricultural subsidies, notably agri-environment payments, will need to be more targeted and evidence based. Currently, it is the larger production-oriented farms that receive the highest payments from both Pillars of the CAP (Herzon et al., 2018; Wynn-Jones, 2013; 
Burton and Schwarz, 2013). Issues of land abandonment and depopulation in environmentally important areas such as the Coomasagharn-Canearagh valley, need a broader approach than a solely agricultural one. It is crucial that the ecological and socio-economic aspects of high nature value farming systems are integrated within a 'joined up' Rural Development Framework (cf. CEDRA, 2014; Lowe and Baldock, 2000; Mitchley et al., 2006). We need to re-establish meaningful links between people and nature that safeguard biodiversity, while creating socioeconomic opportunities to revitalise marginal rural areas. Ultimately, it will be a political and societal choice that will decide whether we maintain a lived-in countryside or a marginal and abandoned one.

\section{Acknowledgements}

I wish to sincerely thank all the hill sheep farmers and other interviewees who participated in this research. I would also like to thank the two referees for their constructive comments. The author declares that she has no conflict of interest.

Academic references

[1] Acs, S., Hanley, N., Dallimer, M., Gaston, K. J., Robertson, P., Wilson, P. \& Armsworth, P. R. (2010). The effect of decoupling on marginal agricultural systems: Implications for farm income, land use and upland ecology. Land Use Policy, 27(2), 550-560. DOI: 10.1016/j.landusepol.2009.07.009.

[2] Adams, W. M. (2003). Future Nature: A vision for conservation $3^{\text {rd }}$ ed. London: Routledge.

[3] Anderson, R. (2013). Biodiversity Change in the Irish Uplands - the effects of grazing management [unpublished PhD Thesis]. Cork: National University of Ireland.

[4] Antrop, M. (2005). Why landscapes of the past are important for the future. Landscape and Urban Planning, 70(1-2), 21-34. DOI: 10.1016/j.landurbplan.2003.10.002.

[5] Backshall, J., Manley, J. \& Rebane, M., eds. (2001). The Upland Management Handbook. Peterborough: English Nature.

[6] Baldock, D., Beaufoy, G., Brouwer, F. \& Godeschalk, F. (1996). Farming at the Margins: Abandonment or Redeployment of Agricultural Land in Europe. London/The Hague: Institute for European Environmental Policy Agricultural Economics Research Institute.

[7] Bignal, E. M. \& McCracken, D. I. (1996). Low-intensity farming systems in the conservation of the countryside. Journal of Applied Ecology 33(3), 413-424.

[8] Bignal, E. M. \& McCracken, D. I. (2000). The Nature conservation Value of European Traditional Farming Systems. Environmental Reviews 8(3), 149-171. DOI: 10.1139/a00-009.

[9] Bonn, A., Allott, T., Hubacek, K. \& Steward, J., eds. (2009). Drivers of Environmental Change in Uplands. London: Routledge.

[10] Buijs, A. E., Pedroli, B. \& Luginbuhl, Y. (2006). From hiking through farmland to farming in a leisure landscape: changing social perceptions of the European landscape. Landscape Ecology, 21(3), 375-389. DOI: 10.1007/s10980-005-5223-2.

[11] Burton, R. J. F., Schwarz, G., Brown, K. M., Convery, I. \& Mansfield, L. (2009). The future of public goods provision in upland regions: Learning from hefted commons in the Lake District, UK. In Bonn, A., Allott, T., Hubacek, K. \& Steward, J., eds., Drivers of Environmental Change in Uplands (pp. 309-322). London: Routledge.

[12] Burton, R. J. F., Paragahawewa, U. H. (2011). Creating culturally sustainable agrienvironmental schemes. Journal of Rural Studies 27(1), 95-104. DOI: 10.1016/j.jrurstud.2010.11.001. 
[13] Burton, R. J. F. \& Schwarz, G. (2013). Result-oriented agri-environmental schemes in Europe and their potential for promoting behavioural change. Land Use Policy, 30/1), 628641. DOI: 10.1016/j.landusepol.2012.05.002.

[14] Cocca, G., Sturaro, E., Gallo, L. \& Ramazin, M. (2012). Is the abandonment of traditional livestock farming systems the main driver of mountain landscape change in the Alpine area? Land Use Policy, 29(4), 878-886. DOI: 10.1016/j.landusepol.2012.01.005.

[15] Conti, G. \& Fagarazzi, L. (2004). Sustainable mountain development and the key-issue of abandonment of marginal rural areas. PLANUM: The European on line - journal of planning Nr. 9 (www.planum.net).

[16] Crowley, C., O'Keeffe, B. \& O'Sullivan, S. (2016). Irish Uplands Socio-Economic Profile: A Report into Ireland's inhabited and farmed upland areas [report commissioned by the Irish Uplands Forum] (www.irishuplandsforum.org).

[17] Daugstad, K., Ronningen, K. \& Skar, B. (2006). Agriculture as an upholder of cultural heritage? Conceptualizations and value judgements - a Norwegian perspective in international context. Journal of Rural Studies, 22(1), 67-81. DOI: 10.1016/j.jrurstud.2005.06.002.

[18] Dillon, E., Moran, B. \& Donnellan, T. (2016). Teagasc National Farm Survey Results 2016. Rural Economy Development Programme. Galway: Teagasc, Athenry, Co.

[19] Evans, D. M., Redpath, S. M., Elston, D. A., Evans, S. A., Mitchel, R. J. \& Dennis, P. (2006). To graze or not to graze? Sheep, voles, forestry and nature conservation in the British uplands. Journal of Applied Ecology 43(3), 499-505. DOI: 10.1111/j.13652664.2006.01158.x.

[20] Fischer, J., Hartel, T. \& Kuemmerle, T. (2012). Conservation policy in traditional farming landscapes. Conservation Letters, 5(3), 167-175. DOI: 10.1111/j.1755-263X.2012.00227.x.

[21] Flemsæter, F. \& Setten, G. (2006). Holding property in trust: Kinship, law and property enactment on Norwegian smallholdings. Environment and Planning A, 41(9), 2267-2284. DOI: $10.1068 / \mathrm{a} 41135$.

[22] Grime, J. P. (1979). Plant Strategies and Vegetation Processes. Chichester: Wiley.

[23] Halada, L., Evans, D., Romăo, C. \& Petersen, J-E. (2011). Which habitats of European importance depend on agricultural practices? Biodiversity and Conservation 20(11), 23652378. DOI: 10.1007/s10531-011-9989-z.

[24] Hanley, N., Davies, A., Angelopoulos, K., Hamilton, A., Ross, A., Tinch, D. \& Watson, F. (2008). Economic Determinants of Biodiversity Change over a 400 -year period in the Scottish Uplands. Journal of Applied Ecology, 45(6), 1557-1565. DOI: 10.1111/j.13652664.2008.01570.x.

[25] Hanley, N., Colombo, S., Mason, P. \& Johns, H. (2007). The reform of support mechanisms for upland farming: paying for public goods in the Severely Disadvantaged Areas of England. Journal of Agricultural Economics, 58(3), 433-453. DOI: 10.1111/j.1477-9552.2007.00114.x.

[26] Hanrahan, K., Hennessy, T., Kinsella, A. \& Moran, B. (2014). Teagasc National Farm Survey Results 2013. Rural Economy Development Programme. Galway: Teagasc, Athenry, Co.

[27] Hampicke, U. (2006). Efficient conservation in Europe's agricultural countryside - rational, methods and policy reorientation. Outlook on Agriculture 35(2), 97-205. DOI: $10.5367 / 000000006777641598$.

[28] Herzon, I., Birge, T., Allen, B., Povellato, A., Vanni, F., Hart, K., Radley, G., Tucker, D., Keenleyside, C., Uppermann, R., Underwood, C., Roux, X., Beaufroy, G. \& Pražan, J. (2018). Time to look for evidence: Results-based approaches to biodiversity conservation on farmland in Europe. Land Use Policy 71, 347-354. DOI: 10.1016/j.landusepol.2017.12.011. 
[29] Höchtl, F. Lehringer, S. \& Konold, W. (2005). "Wilderness": What it means when it becomes a reality - a case study from the southwestern Alps. Landscape and Urban Planning, 70(12), 85-95. DOI: 10.1016/j.landurbplan.2003.10.006.

[30] Jørgensen, D. (2015). Rethinking rewilding. Geoforum 65, 482-488. DOI: 10.1016/j.geoforum.2014.11.016.

[31] Keenleyside, C. \& Tucker, G. (2010). Farmland Abandonment in the EU: An assessment of trends and future prospects [research report]. London: Institute for European Environmental Policy.

[32] Keenleyside, C., Radley, G., Tucker, G., Underwood, E., Hart, K., Allen, B. \& Menadue, H. (2014). Results-based Payments for Biodiversity Guidance Handbook: Designing and implementing results-based agri-environment schemes 2014-20 [research report]. London: Institute for European Environmental Policy.

[33] Kinsella, J., Wilson, S., de Jong, F., Renting, H. (2000). Pluriactivity as a Livelihood Strategy on Irish farm Households and its Role in Rural Development. Sociologia Ruralis 40(4), 481496. DOI: $10.1111 / 1467-9523.00162$.

[34] Kramm, N, Anderson, R., O'Rourke, E., Emmerson, E., O'Halloran, J. \& Chisholm, N. (2010). Farming the Iveragh Uplands: A tale of humans and nature. University College Cork.

[35] Kristensen, L. S., Thenail, C. \& Kristensen, S. P. (2004). Landscape change in agrarian landscapes in the 1990: the interaction between farmers and the farmed landscape. A case study from Jutland, Denmark. Journal of Environmental Management, 71(3), 231-244. DOI: 10.1016/j.jenvman.2004.03.003.

[36] Lambin, E. F., Geist, H. J. \& Lepers, E. (2003). Dynamics of land-use and land-cover change in tropical regions. Annual Review of Environmental Resources, 28, 205-241. DOI: 10.1146/annurev.energy.28.050302.105459.

[37] López-i-Gelats, F., Milán, M. J. \& Bartolomé, J. (2011). Is farming enough in mountain areas? Farm diversification in the Pyrenees. Land Use Policy, 28(4), 783-791. DOI: 10.1016/j.landusepol.2011.01.005.

[38] Lowe, P. \& Baldock, D. (2000). Integration of environmental objectives into agricultural policy making. In Brouwer, F. \& Lowe, P., eds., CAP Regimes and the European Countryside (pp. 31-52). Wallingford: CABI Publications.

[39] MacDonald, D., Crabtree, J. R., Wiesinger, G., Dax, T., Stamou, N., Fleury, P., Gutierrez Lazpita, J. \& Gibson, A. (2000). Agricultural abandonment in mountain areas of Europe: Environmental consequences and policy response. Journal of Environmental Management, 59(1), 47-69. DOI: 10.1006/jema.1999.0335.

[40] Mansfield, L. (2008). The Cumbrian Hill Sheep Initiative: A Solution to the Decline in Upland Hill Farming Community in England? In Robinson, G. M., ed., Sustainable Rural Systems, Sustainable Agriculture and Rural Communities (pp. 161-183). Farnham: Ashgate.

[41] Mansfield, L. (2011). Upland Agriculture and the Environment. Bowness-on-Windemere: Badger Press.

[42] Marini, L., Klimek, S. \& Battisti, A. (2011). Mitigating the impacts of the decline of traditional farming on mountain landscapes and biodiversity: A case study in the European Alps. Environmental Science and Policy, 14(3), 258-267. DOI: 10.1016/j.envsci.2010.12.003.

[43] Mitchley, J., Price, M. F. \& Tzanopoulos, J. (2006). Integrated Futures for Europe's Mountain Regions: Reconciling Biodiversity Conservation and Human Livelihoods. Journal of Mountain Science, 3(4), 276-286. DOI: 10.1007/s11629-006-0276-5.

[44] Mottet, A., Ladet, S., Coqué, N. \& Gibon, A. (2006). Agricultural land-use change and its drivers in mountain landscapes: A case study in the Pyrenees. Agriculture Ecosystems and Environment 114(2-4), 296-310. DOI: 10.1016/j.agee.2005.11.017. 
[45] Navarro, L. M. \& Pereira, H. M. (2012). Rewilding abandoned landscapes in Europe. Ecosystems, 15(6), 900-912. DOI: 10.1007/s10021-012-9558-7.

[46] O'Rourke, E., Charbonneau, M. \& Poinsot, Y. (2016). High nature value mountain farming systems in Europe: Case Studies from the Atlantic Pyrenees, France and the Kerry Uplands, Ireland. Journal of Rural Studies, 46, 47-59. DOI: 10.1016/j.jrurstud.2016.05.010.

[47] O'Rourke, E. \& Kramm, N. (2009). Changes in the Management of the Irish Uplands: a CaseStudy from the Iveragh Peninsula. European Countryside, 1(1), 53-69. DOI: 10.2478/v10091-009-0005-5.

[48] O'Rourke, E., Kramm, N. \& Chisholm, N. (2012). The influence of farming styles on the management of the Iveragh uplands, southwest Ireland. Land Use Policy, 29(4), 805816. DOI: 10.1016/j.landusepol.2011.12.008.

[49] Ostrom, E. (1990). Governing the Commons: the evolution of institutions for collective action. Cambridge University Press.

[50] Paniagua, A. (2013). Farmers in remote rural areas: The worth of permanence in the place. Land Use Policy 35, 1-7. DOI: 10.1016/j.landusepol.2013.04.017.

[51] Paracchini, M. L., Petersen, L-E., Hoogeveen, Y., Bamps, C., Burfield, I. \& van Swaay, C. (2008). High Nature Value Framing in Europe. As estimate of the distribution patterns on the basis of land cover and biodiversity data. Luxembourg: Office for Official Publications of the European Communities.

[52] Pinto-Correia, T., Gustavsson, R. \& Pirnat, J. (2006). Bridging the gap between centrally defined policies and local decisions - Towards more sensitive and creative rural landscape management. Landscape Ecology, 21(3), 333-346. DOI: 10.1007/s10980-005-4720-7.

[53] Pinto-Correia, T. \& Sørensen, E. M. (1995). Marginalisation and marginal land: processes of change in the countryside. Skriftserie, 152.

[54] Plieninger, T. \& Bieling, C. (2013). Resilience-Based Perspectives to Guiding High-NatureValue Farmland through Socioeconomic Change. Ecology and Society 18(4): 20. DOI: 10.5751/ES-05877-180420.

[55] Plieninger, T., Hochtl, F. \& Spek, T. (2006). Traditional land-use and nature conservation in European rural landscapes. Environmental Science and Policy, 9(4), 317-321. DOI: 10.1016/j.envsci.2006.03.001.

[56] Pointereau, P., Coulon, F., Girard, P., Lambotte, M., Stuczynski, T., Sanchez Ortega, V. \& Del Rio, A. (2008). Analysis of Farmland Abandonment and the Extent and Location of Agricultural Areas that are Actually Abandoned or at Risk of Abandonment [research report]. Luxembourg: Office for Official Publications of the European Communities.

[57] Prishchepov, A. V., Muller, D., Dubinin, M., Baumann, M. \& Radeloff, V. C. (2013). Determinants of agricultural land abandonment in post-Soviet European Russia. Land Use Policy, 30(1), 873-884. DOI: 10.1016/j.landusepol.2012.06.011.

[58] Rackham, O. (2000). The History of the Countryside. London: Phoenix Press.

[59] Rebanks, J. (2016). The Shepherd's Life: A Tale of the Lake District. London: Penguin Books.

[60] Renting, H., Oostindie, H., Laurent, C., Brunori, G., Barjolle, D., Jervell, A. M., Granberg, L. \& Heinonen, M. (2008). Multifunctionality of agricultural activities, changing rural identities and new institutional arrangements. International Journal of Agricultural Resources, Governance and Ecology, 7(4), 361-385. DOI: 10.1504/IJARGE.2008.020083.

[61] Renwick, A., Jansson, T., Verburg, P. H., Revoredo-Giha, C., Britz, W., Gocht, A. \& McCracken, D. (2013). Policy reform and agricultural land abandonment in the EU. Land Use Policy 30(1), 446-457. DOI: 10.1016/j.landusepol.2012.04.005.

[62] Rey Benayas, J. M., Martins, A., Nicolau, J. M. \& Schulz, J. J. (2007). Abandonment of agricultural land: an overview of drivers and consequences. CAB Reviews: Perspectives in 
Agriculture, Veterinary Science, Nutrition and Natural Resources 2, 57. DOI: 10.1079/PAVSNNR20072057.

[63] Selman, P. (2004). Barriers and bridges to sustainable cultural landscapes. In Jongman, R., ed., The New Dimensions of the European Landscape (pp. 93-102). Frontis: Wageningen.

[64] Shucksmith, M. \& Ronningen, K. (2011). The Uplands after neoliberalism? - The role of the small farm in rural sustainability. Journal of Rural Studies, 27(3), 275-287. DOI: 10.1016/j.jrurstud.2011.03.003.

[65] Strijker, D. (2005). Marginal Lands in Europe - causes of decline. Basic and Applied Ecology 6(2), 99-106. DOI: 10.1016/j.baae.2005.01.001.

[66] Terres, J-M., Scacchiafichi, L. N., Wania, A., Ambar, M., Anguiano, E., Buckwell, A., Coppola, A., Gocht, A., Nordstrom Kallstrom, H., Pointereau, P., Strijker, D., Visek, L., Vranken, L. \& Zobena, A. (2015). Farmland abandonment in Europe: Identification of drivers and indicators, and development of a composite indicator of risk. Land Use Policy 49, 20-34. DOI: 10.1016/j.landusepol.2015.06.009.

[67] Vera, F. (2000). Grazing Ecology and Forest History. Wallingford: CABI.

[68] Verburg, P. H., van Berkel, D., van Doorn, A., van Eupen, M. \& van den Heiligenberg, R. (2010). Trajectories of land use change in Europe: A model based exploration of rural futures. Landscape Ecology 25(2) 217-232. DOI: 10.1007/s10980-009-9347-7.

[69] Verburg, P. H., Veldkamp, A., Espaldon, R. L. V., Mastura, S. S. A. (2002). Modelling the spatial dynamics of regional land use: the CLUE-S model. Environmental Management, 30(3), 391-405. DOI: 10.1007/s00267-002-2630-x.

[70] Verburg, P. H. \& Overmars, K. (2009). Combining top-down and bottom-up dynamics in land use modelling: exploring the future of abandoned farmlands in Europe with the Dyna-CLUE model. Landscape Ecology 24, 1167-1181. DOI: 10.1007/s10980-009-9355-7.

[71] Wilson, G. (2001). From productivism to post-productivism and back again? Exploring the (un)changed natural and mental landscapes of European agriculture. Transactions of the Institute of British Geographers, 26(1), 77-102.

[72] Wynn-Jones, S. (2013). Connecting payments for ecosystem services and agri-environment regulation: An analysis of the Welsh Glastir Scheme. Journal of Rural Studies 31, 77-86. DOI: 10.1016/j.jrurstud.2013.01.004.

Other sources

[73] CEDRA (2014). Report of the Commission for the Economic Development of Rural Areas. Department of the Environment, Community and Local Government. Dublin. (www.ruralireland.ie)

[74] Census of Agriculture 1933 to 2011, Central Statistics Office (CSO), Dublin.

[75] Census of Population 2011 and 2016. Central Statistics Office (CSO), Dublin.

[76] Cork Declaration, 1996, (http://ec.europa.eu/agriculture/rur/cork_en.htm).

[77] CRC (2010). Commission for Rural Communities: high ground, high potential - a future for England's upland communities. Cheltenham (www. ruralcommunities.gov.uk).

[78] EEA - European Environment Agency (2010). Approximate distribution of HNV farmland in EU-27. European Environmental Agency, Copenhagen, Denmark.

[79] EEA - European Environment Agency (2004) High Nature Value Farmland: Characteristics, trends and policy challenge. Report by European Environment Agency, Copenhagen, Denmark. 
[80] European Habitats Directive (Directive 92/43, EEC of 21 May 1992), Brussels. http://eurlex.europa.eu/legal-content/EN/TXT/?uri=CELEX:31992L0043 (accessed 21/08/2017).

[81] www.mountaineering.ie. Department of the Environment, Community and Local Government (2013), Recreation in the Irish Countryside: Property rights, obligations and responsibilities, $12 \mathrm{p}$.

[82] www.prai.ie. Property Registration Authority, Land Registry, Ireland.

[83] www.met.ie. Met Éireann, The Irish Meteorological Service Online. 